\title{
ARAH HUKUM EKONOMI \\ DALAM PENGEMBANGAN \\ PEREKONOMIAN INDONESIA
}

\author{
Acep Rohendi \\ Universitas BSI \\ arohendi1209@gmail.com
}

\begin{abstract}
Abstrak
Para pendiri negara telah menetapkan sistem ekonomi Indonesia sebagaimana diatur dalam Pasal 33 UUD 1945, suatu sistem ekonomi yang bukan sosialis maupun kapitalis. Namun pada prakteknya menjalankan sistem kapitalis yang merupakan cikal bakal liberalisasi ekonomi dalam hukum ekonomi Indonesia. Hukum ekonomi Indonesia tersebut merupakan produk hukum berupa peraturan perundang-undangan yang seharusnya merupakan penjabaran Pasal 33 UUD 1945. Sistem ekonomi dalam UUD 45 bukan merupakan sistem ekonomi kapitalis, namun sistem ekonomi yang berasaskan kekeluargaan. Kebutuhan pragmatis menyebabkan liberasi ekonomi sehingga timbulnya hukum ekonomi bercorak kapitalis.dengan keikutsertaan menjadi anggota dari forum forum /organisasi internasional, yang anggota meliberasi sistem ekonominya. Mau tidak mau negara Indonesai terikat untuk meliberaliasi sistem ekonominya. Perlu kembalinya kepada UUD 45 sebelum amandemen merupakan salah satu upaya mengembalikan rel system ekonomi yang dikehendaki Pasal 33 UUD 1945. Adanya GBHN diperlukan untuk memformat ulang sistem ekonomi kapitalistik kembali kepada sistem ekonomi yang berlandaskan Pasal 33 UUD 45. Penjabaran GBHN tersebut dapat dibuat produk hukum ekonomi Indonesia yang mencerminkan pasal-pasal dari Pasal 33 UUD 1945.
\end{abstract}

Kata kunci : sistem ekonomi, liberalisasi ekonomi, asas kekeluargaan

\section{Abstract}

Article 33 of the 1945 Constitution, an economic system that is neither socialist nor capitalist. But in practice running the capitalist system which is the forerunner to economic liberalization in Indonesian economic law. The Indonesian economic law is a legal product in 
the form of laws and regulations which should be an elaboration of Article 33 of the 1945 Constitution. The economic system in the 1945 Constitution is not a capitalist economic system, but a family-based economic system. Pragmatic needs lead to economic liberation so that capitalist-style economic law arises. With the participation of being a member of an international forum / organization forum, which members liberate the economic system. Like it or not the Indonesian state is bound to liberalize its economic system. The need to return to the 1945 Constitution before the amendment is one of the efforts to restore the desired economic system rail Article 33 of the 1945 Constitution. The existence of the GBHN is needed to reformat the capitalistic economic system back to the economic system based on Article 33 of the 1945 Constitution. Indonesia, which reflects the articles of Article 33 of the 1945 Constitution.

Keywords: economic system, economic liberalization, the principle of kinship

\section{A. Latar Belakang}

Secara umum hukum Ekonomi, menurut Sumantoro, sebagai "seperangkat norma-norma yang mengatur hubungan kegiatan ekonomi yang secara substansil sangat dipengaruhi oleh sistem ekonomi yang digunakan oleh sesuatu negara (liberalis, sosialis, atau campuran)".' Sejalan dengan pengertian tersebut, terkait dengan pembahas pembangunan hukum ekonomi sebelumnya harus memahami terlebih dahulu sistem ekonomi di laksanakan di Indonesia. Sejalan dengan itu Adi Sulistyono berpendapat bahwa :

"Berbicara tentang pembangunan hukum ekonomi, mau tidak mau kita harus memahami sistem ekonominya. Terdapat hubungan yang sangat erat dan timbal balik antara sistem hukum dengan sistem ekonomi. Berkaitan dengan hal ini sebaiknya secara nasional harus disepakati sistem ekonomi yang digunakan di Indonesia, apa kita akan mengabdi pada sistem ekonomi kapitalis, yang mengkultuskan pasar bebas, atau sistem ekonomi Pancasila, yang cenderung berpihak pada ekonomi rakyat sebagaimana telah ditegaskan dalam Pasal 33 UUD 1945."

Sumantoro, Hukum Ekonomi, Jakarta : UI-Press,2008, hlm.31

Adi Sulistyono, "Pembangunan Hukum Ekonomi Untuk Mendukung Pencapaian Visi Indonesia 2030" Pidato Pengukuhan Guru Besar Hukum Ekonomi Pada Fakultas Hukum UNS, Surakarta,17 Nopember 2007,hlm.8 
Sistem ekonomi liberal dalam liberalisasi ekonomi telah menjadi kebijakan utama diperkenalkan di negara-negara berkembang sejak akhir 1970an, yang sebagian besar dikaitkan dengan syarat pinjaman yang ditetapkan oleh lembaga keuangan internasional. Kebijakan liberalsiasi ini, pemerintah diarahkan untuk mengikuti non-intervensionis, laissez-faire, yaitu pendekatan kegiatan ekonomi yang mengandalkan pasar dalam alokasi alokasi sumber daya. Reformasi kebijakan ini diyakini akan memacu pertumbuhan dan mempercepat pengurangan kemiskinan.

Woodward menjelaskan Liberalisasi ekonomi sebagai berikut :

"Economic liberalization encompasses the processes, including government policies, that promote free trade, deregulation, elimination of subsidies, price controls and rationing systems, and, often, the downsizing or privatization of public services". ${ }^{3}$

Liberalisasi ekonomi, menurut Woodward meliputi proses-proses yang meliputi kebijakan pemerintah, yang mendukung perdagangan bebas, deregulasi, penghapusan mengenai subsidi, kontrol harga dan sistem penjatahan, dan, sering, mengurangi pengecilan atau privatisasi pelayanan publik.

Negara yang menerapkan liberalisasi ekonomi berarti negara tersebut "membuka diri" ke seluruh dunia berkaitan dengan perdagangan, peraturan, perpajakan dan daerah lain yang umumnya mempengaruhi bisnis di negara ini. Sebagai aturan umum, liberalisasi ekonomi menunjukkan betapa mudahnya untuk berinvestasi dan melakukan bisnis di negara ini. ${ }^{4}$

Liberalisasi ekonomi umumnya diterapkan di negara-negara yang menganut sistem ekonomi kapitalistik, yang kemudian berkembang diterapkan di negara-negara berkembang dalam pengembangan perekonomiannya, termasuk negara Indonesia. Padahal Indonesia sejatinya tidak menganut sstem ekonomi kapitalistik, sebab seharusnya sistem ekonomi Indonesia bersumber kepada Pasal 33 UUD 45 (Undang-Undang Dasar 1945). Oleh karena itu, sistem ekonomi Indonesia yang terjadi dewasa ini perlu dikaji akar penyebabnya, agar di suatu ketika system ekonomi berdasarkan Pasal 33 UUD 45 dapat terwujud.

3 The United Nation, "Economic liberalization and poverty reduction", <http://www.un.org/esa/ socdev/rwss/docs/2010/chapter6.>,[12/11/2015].

4 Joseph Nguyen," 5 Economic Effects Of Country Liberalization",<http://www.investopedia.com/ articles/economics/11/economic-benefits-country-liberalization.asp?layout=orig.>,[15/11/2015\}. 


\section{B. Hubungan Sistem Ekonomi dengan Ideologi Negara}

Pengembangan perekonomian Indonesia merupakan proses, cara Pemerintah Indonesia mengembangkan tata kehidupan perekonomian negara untuk mencapai sasaran yang dikehendaki. Pengembangan ekonomi merupakan upaya aktif dari Pemerintah Indonesia untuk mengembangkan pembangunan ekonomi secara bertahap dan teratur sesuai dengan tujuan pembangunan ekonomi.

Pengembangan perekonomian suatu negara berkaitan dengan penerapan sistem ekonomi. Dumairi menjelaskan sistem ekonomi sebagai berikut:

"sistem ekonomi adalah suatu sistem yang mengatur serta menjalin hubungan ekonomiantarmanusia dengan seperangkat kelembagaan dalam suatu tatanan kehidupan. Sebuah sistem ekonomi terdiri atas unsur-unsur manusia sebagai subyek; barang-barang ekonomi sebagai obyek serta seperangkat kelembagaan yang mengatur dan menjalin dalam kegiatan berekonomi.Perangkat kelembagaan yang dimaksud meliputi lembaga-lembaga ekonomi (formal maupun nonformal);cara kerja; mekanisme hubungan; hukum dan peraturan perekonomian serta kaidah dan norma-norma lain (tertulis maupun tidak tertulis;yang diterima atau ditetapkan oleh masyarakat... Suatu sistem ekonomi tidaklah berdiri sendiri.la berkaitan dengan falsafah,pandangan dan pola hidup masyarakat tempat berpijak..... la bagian dari kesatuan ideologi kehidupan bermasyarakat di suatu negara"s

Sistem ekonomi sebuah sistem di dalamnya terdapat unsur-unsur kelembagaan yang mengatur interaksi yang terjadi dalam kegiatan berekonomi yaitu hukum dan peraturan perekonomian serta kaidah dan norma-norma lain (tertulis maupun tidak tertulis;yang diterima atau ditetapkan oleh masyarakat.

Sistem ekonomi merupakan bagian integral dari ideologi suatu negara. Artinya suatu sistem ekonomi harus berlandaskan kepada ideologi suatu negara. Seperti sistem ekonomi Indonesia berkaitan dengan kaidah-kaidah I norma-norma yang berlandaskan suatu ideologi negara yang berlaku di Indonesia. Bukan sebaliknya. ideologi negara mengikuti system ekonomi yang berjalan. Dalam hal ini maka, hukum ekonomi di Indonesia merupakan norma-norma hukum yang mengatur sistem perekenomian suatu negara berlandaskan ideologi negara Indonesia, yaitu Pancasila. ${ }^{6}$

5 Dumairy, Perekonomian Indonesia, Jakarta :Erlangga;1996,hlm.30.

6 “ideologi/ide·o·lo·gi//idéologi/ n1 kumpulan konsep bersistem yang dijadikan asas pendapat (kejadian) yang memberikan arah dan tujuan untuk kelangsungan hidup: dalam pertemuan itu penatar menjelaskan dasar -- negara<http://kbbi.web.id/ideologi >.[22/10/2015]. 
Sistem ekonomi berkaitan berkaitan erat dengan sistem-sistem sosial lain yang berlangsung di dalam masyarakat. Menurut Dumairi di dunia ini terdapat kecenderungan umum bahwa sistem ekonomi di sebuah negara "bergandengan tangan" dengan sistem politik di negara yang bersangkutan, ideologi ekonomi berjalan dengan seiring dengan ideologi politik.

Secara umum, antara unsur-unsur sistem ekonomi dan unsure-unsur system politik dapat ditarik benang merah (keterkaitan) sebagai berikut : karakteristik hubungan sistem ekonomi dengan sistem politik. Karakteristik ekstrim dari "Kutub A" adalah Liberalisme (Liberal),Demokrasi (demokrasi), Egalitarisme (Egaliter), Desentralisasi (desentralis ), Kapitalisme (kapitalis) dan Mekanisme pasar. Sebaliknya Karakteristik ekstrim dari “Kutub Z” adalah Komunisme (komunis), Otokrasi (otoriter), Etatisme (etatis), Sentralisme (sentralis), Sosialisme (Sosialis), dan Perencanaan Terpusat. ${ }^{7}$

Hubungan Sistem Ekonomi dengan Sistem Politik dijelaskan oleh Dumairi dengan membuat tabel yang terdiri dari dua kutub yaitui kutub A dan kutub Z, di antara dua kutub tersebut terdapat "konteks pengkutuban seperti gambar berikut ini :

\begin{tabular}{|ccc|}
\hline "Kutub A" & Konteks Pengkutuban & "Kutub Z" \\
\hline $\begin{array}{c}\text { Liberalisme } \\
\text { (Liberal) }\end{array}$ & Ideologi Politik & $\begin{array}{c}\text { Komunisme } \\
\text { (komunis) }\end{array}$ \\
$\begin{array}{c}\text { Demokrasi } \\
\text { (demokrasi) }\end{array}$ & $\begin{array}{c}\text { Rejim pemerintahan } \\
\text { (cara memerintah) }\end{array}$ & $\begin{array}{c}\text { Otokrasi } \\
\text { (otoriter) }\end{array}$ \\
$\begin{array}{c}\text { Egalitarisme } \\
\text { (Egaliter) }\end{array}$ & Penyelenggaraan negara & $\begin{array}{c}\text { Etatisme } \\
\text { (etatis) }\end{array}$ \\
$\begin{array}{c}\text { Desentralisasi } \\
\text { (desentralis) }\end{array}$ & Struktur birokrasi & $\begin{array}{c}\text { Sentralisme } \\
\text { (sentralis) }\end{array}$ \\
Kapitalisme & Ideologi ekonomi & $\begin{array}{c}\text { Sosialisme } \\
\text { (kapitalis) }\end{array}$ \\
Mekanisme Pasar & Pengelolaan Ekonomi & Perencanaan \\
& & Terpusat \\
\hline
\end{tabular}

Sumber : Dumairi, 1996

7 Dumairy, Ibid. hlm.31 
Terdapat tiga aspek yang dijadikan kriteria untuk menentukan sistem ekonomi suatu negara, yang meliputi Kutub " $A$ " (Sistem Ekonomi Kapitalis) dan Kutub "Z" (Sistem Ekonomi Sosialis) atau Sistem Ekonomi Campuran (campuran antara Sistem Ekonomi Kapitalis dengan Sistem Ekonomi Sosialis), yaitu :

"a. berdasarkan tiga sudut tinjauan tadi ${ }^{8}$, seperti :

1) Sistem pemilikan sumber daya atau factor-faktor produksi;

2) Keleluasaan masyarakat untuk saling berkompetisi satu sama lain dan untuk menerima imbalan atau prestasi kerjanya;

3) Kadar peranan pemerintah dalam mengatur, mengarahkan, dan merencanakan kehidupan bisnis dan perekonomian pada umumnya 9

b. berdasarkan hukum, perilaku, norma dan etika yang berlaku atau dianut oleh masyarakat dalam berekonomi;

c. berdasarkan tinjuan pengalaman kornologis."

Tolok ukur sistem ekonomi kapitalis adalah sebagai berikut :

1). Mengakui pemilikan individu atas sumber daya atau faktor-faktor produksi,

2). Mengakui keleluasaan masyarakat untuk saling berkompetisi satu sama lain memiliki sumber daya, kompetisi antar individu dalam memenuhi kebutuhan hidup, persaingan antarbadan usaha dalam mengejar keuntungan sangat dihargai. Tidak ada batasan bagi individu dalam menerima atas prestasi kerjanya,

3). Campur tangan pemerintah atau negara sangat minim. Pemerintah lebih berkedudukan sebagai pengamat dan pelindung perekonomian"

Sistem ekonomi kapitalis, dalam teori ekonomi mikro, merupakan sistem ekonomi yang menyandarkan diri sepenuhnya pada mekanisme pasar, berdasarkan prinsip laissez faire (persaingan bebas) dan meyakini kemampuan(the invisible hand) dalam menuju efisiensi ekonomi. Mekanisme pasarlah (kekuatan permintaan dan penawaran) yang menurut kalangan kapitalis - akan menentukan secara efisien ketiga pokok persoalan ekonomi, yaitu apa yang harus diproduksi (what), bagaimana memproduksi (how) dan untuk siapa diproduksi (for whom)."

8 "Sistem ekonomi suatu negara dikatakan bersifat khas, sehingga bis dibedakan dari system ekonomi yang berlaku atau diterapkan di negara lain". ( Dumairi, hlm.32)

9 Dumairy, Op.Cit,.hlm.32

$10 \mathrm{lbid}, . \mathrm{hlm} .33$

11 Ibid, hlm.32. 


\section{Pergeseran Peran Negara Dalam Liberalisasi Ekonomi}

Sistem ekonomi kapitalis yang menentukan gerak perekonomian adalah pasar, karena minimnya campur tangan pemerintah. Kebijakan pemerintah yang mengurangi campur tangan pemerintah dalam perekonomian serta mengurangi pembatasan keterlibatan swasta dalam perekonomian dengan memberi kesempatan yang besar kepada sektor swasta untuk berperan aktif dalam perekonomian, dinamakan Liberalisasi ekonomi. Bahkan dalam pengertian yang lebih ekstrim liberalisasi ekonomi dalam penghapusan kontrol pemerintah dalam mendorong pembangunan ekonomi. ${ }^{12}$

Pengertiantersebutmenunjukkanbahwaliberalisasiekonomimerupakan suatu proses pergeseran aktifitas ekonomi dalam pembangunan ekonomi yang semula kegiatan ekonomi yang merupakan pelaku ekonomi utama dikerjakan oleh negara bergeser kepada sektor swasta dengan memberi peran lebih besar untuk melakukan aktifitas ekonomi.

Liberalisasi ekonomi merupakan kebijakan pemerintah yang mengurangi campur tangan pemerintah dalam perekonomian serta mengurangi pembatasan keterlibatan swasta dalam perekonomian dengan memberi kesempatan yang besar kepada sektor swasta untuk berperan aktif dalam perekonomian. Bahkan dalam pengertian yang lebih ekstrim liberalisasi dalam penghapusan kontrol pemerintah dalam mendorong pembangunan ekonomi. ${ }^{13}$

“1). Sumber daya ekonomi atau faktor produksi diklaim sebagai milik pemerintah.

2). Sistem ini lebih menekankan pada kebersamaan masyarakat dalam menjalankan dan memajukan perekonomian. Imbalan yang diterima orang perorang didasarkan pada kebutuhan bukan berdasarkan jasa yang diberikan. Prinsip keadilan dalam sosialis setiap orang menerima imbalan yang sama,

3). Kadar campur tangan pemerintah atau negara sangat tinggi. Pemerintahlah yang menentukan dan merencanakan tiga pokok persoalan ekonomi : apa yang harus diproduksi (what), bagaimana memproduksinya (how), dan untuk siapa produksi (for whom)."”

\footnotetext{
12 Wikipedia, the free encyclopedia, "Economic liberalization", <https://en.wikipedia.org/wiki/ Economic_liberalization>, [02/09/2015]. 


\section{Sistem Ekonomi Sosialis Dalam Negara Berkembang}

Sebaliknya dari sistem kapitalis secara ekstrim adalah sistem ekonomi sosialis. Tolok ukur sistem ekonomi sosialis, adalah sebagai berikut :

Sistem ekonomi sosialis adalah sistem ekonomi yang menyoroti pasar justru harus dikendalikan melalui perencanaan pusat. Adanya distorsi dalam mekanisme pasar, menyebabkan tidak mungkin bekerja secara efisien, oleh karena itu pemerintah atau negara harus turut aktif bermain dalam perekonomian. ${ }^{14}$

Sistem ekonomi yang berada di antara sistem ekonomi kapitalis dan sistem ekonomi sosialis adalah sistem ekonomi campuran. Apabila Amerika serikat merupakan negara yang konsisten menerapkan sistem ekonomi kapitalis, sebaliknya Uni Sovyet (sebelum bubar) sebagai negara yang konsisten menjalankan sistem sosialis. ${ }^{15}$

Negara-negara berkembang pada umumnya secara konsisten meramu "resep campurannya", dalam arti kadar kapitalismenya selalui lebih tinggi (contoh Filipina), atau bobot sosialismenya lebih besar (misalnya India). Banyak pula negara berkembang yang goyah meramu campuran kedua sistem ekonomi tersebut. Sistem ekonomi campuran yang diterapkannya ibarat pendulum (bandul jam dinding), kadang-kadang condong ke kapitalis, sementara di lain waktu cenderung sosialistik, mengikuti rejim pemerintahan yang sedang berkuasa. ${ }^{16}$

Ditinjau dari kepemilikan sumber daya ekonomi atau factor-faktor produksi, sepanjang yang tidak menguasai hajat hidup orang banyak, maka tidak terdapat alasan sistem ekonomi Indonesia termasuk sistem ekonomi kapitalis. Demikian pula, Negara Indonesia mengakui kepemilikan individu atas sumber daya., yang tidak menguasai hajat hidup orang banyak, serta iklim persaingan dalam berekonomi bukanlah iklim persaingan yang bebas lepas tanpa kendali pemerintah, maka tidak terdapat alasan sistem ekonomi Indonesia termasuk sistem ekonomi sosialis. Hal ini diatur dengan tegas oleh Pasal 33 UUD 1945, jadi secara konstitusional, sistem ekonomi Indonesia bukan kapitalisme dan bukan pula sosialisme ${ }^{17}$

14 Dumairy, Op.Cit, hlm.32.

15 Ibid

16 Ibid

17 Ibid. 


\section{E. Sistem Ekonomi Indonesia Dalam UUD 1945}

Secara mikro ekonomi, ditinjau dari segi pengelolaan ekonomi Indonesia tidak sepenuhnya menyadarkan perekonomian pada mekanisme pasar, dalam beberapa hal Pemerintah turut bertindak dalam perekonomian. Peran stabilisator dan dinaminsator ini dimainkan baik oleh lembaga-lembaga departemental(instansi teknis) Pemerintah maupun melalui BUMN. ${ }^{18}$

Sanusi berpendapat bahwa sistem ekonomi Indonesia tidak terlepas dari prinsip-prinsip dasar dari pembentukan Republik Indonesia yang tercantum dalam Pancasila dan UUD 1945, sehingga Indonesia menganut sistem ekonomi campuran terutama disesuaikan dengan UUD 1945 sebelum diamandemen tahun 2000, dikenal dengan sistem ekonomi Pancasila, dan setelah tahun 1999,sistem ekonomi dikenal sistem ekonomi kerakyatan. ${ }^{19}$

Pengembangan perekonomian Indonesia ditandai dengan beberapa kesepakatan liberalisasi ekonomi sejak Orde Baru, seperti

a. WTO yang menganut doktrin pasar bebas dalam bidang investasi adalah TRIMs Agreement dan GATS:20

b. AFAS yang merupakan kesepakatan untuk menghilangkan pembatasan perdagangan intra-regional dan memperluas cakupan liberalisasi dalam "GATS-plus". ${ }^{21}$

c. APEC merupakan untuk memperkuat integrasi ekonomi regional dengan menghapus hambatan perdagangan dan investasi ${ }^{22}$

d. IMF menerapkan persyaratan liberalisasi sektor perbankan harus dilakukan Indonesia sesuai dengan kesepakatan Indonesai sebagai anggota WTO. 23

18 Ibid, hlm.34

19 Tulus T.H.Tambunan, Op.Cit., hlm.7 ; Istilah sistem ekonomi ini kerakyatan ditemukan dalam Pasal V TAP PMR No.XVI/MPR/1998, dalam konteks keberpihakan tegas terhadap kelompok usaha ekonomi rakyat serta dalam Undang-Undang Republik Indonesia Nomor 25 Tahun 2000 (25/2000) tentang Program Pembangunan Nasional (Propenas) Tahun 2000-2004.</COMP>

20 WTO, "Trade and Investment " <http://www.wto.org/english/tratop_e/invest_e/invest_e.htm>, [2/10/2013].

21 Gopalan. Sasidaran and Ramkishen S. Pajan, “Financial Sector De-Regulation in Emerging Asia: Focus on Foreign Bank Entry", 13/1/10, < http://www.freewebs.com/rrajan1/bankentry.pdf>, [3/05/3015].,hlm.4

22 Australian Government, Department of Foreign Affairs and Trade, "Asia-Pacific Economic Cooperation (APEC)",tanpa tahun, <http://www.dfat.gov.au/apec/>, [2/05/2014].

23 Zulkarnain Sitompul, “World Trade Organization, International Monetary Fund Dan Perubahan Sistem Perbankan", Pro Justitia, Tahun XVI Nomor 4 Oktober 1998. 
Ruslan Saleh mengkaji hukum ekonomi dengan pendekatan bertolak pada Pasal 33 Undang-Undang Dasar 1945. Eksistensi yang mendasari hukum ekonomi yaitu dari segi pembentukan peraturan perundangan perjabaran Pasal 33 UUD 1945. Menurut pendapatnya dalam penjabaran Pasal 33 UUD 1945 masih terdapat beberapa masalah seperti ${ }^{24}$ :

\section{1) Pembentukan undang-undang selalu dipangaruhi oleh pandangan politik tertentu dan tidak bisa lepas dari situasi politik tersebut.}

Beberapa uraian di muka yang mempengaruhi pembentukan peraturan perundang-undangan bukan hanya peristiwa politik akan tetapi juga peristiwa ekonomi mempengaruhi perundang-undangan seperti kesepakatan-kesepakatan ekonomi baik ditingkat regional dan multinasional mempengaruhi pembentukan perundang-undangan dalam lingkup hukum ekonomi.

Kerjasama internasional yang dilakukan Pemerintah Indonesia dalam WTO, AFAS, APEC atau IMF apabila ditinjau dari beberapa indikator sistem ekonomi kapitalis, telah mengubah Sistem Hukum Ekonomi Campuran berdasarkan Pasal 33 UUD 1945 menuju sistem Ekonomi Kapitalis. Implikasi liberalisasi ekonomi di Indonesia telah mengubah pendulum yang seharusnya berada pada Sistem Ekonomi Campuran menjadi condong ke sebelah kanan, yaitu Sistem Ekonomi Kapitalisme.

\section{2) Pasal 33 UUD 1945 dan UUD 1945 merupakan amanat dari Proklamasi yang bertujuan untuk kemakmuran rakyat.}

Pasal 33 UUD 1945 terkandung perjuangan kemerdekaan bangsa Indonesia termasuk perekonomian. Perlunya tekad yang teguh bahwa masalah pembangunan ekonomi masih merupakan kelanjutan perjuangan kemerdekaan, yaitu perjuangan untuk membebaskan rakyat dari kemiskinan, kebodohan dan keterbelakangan yang terjadi dalam masyarakat.

Pendapat penulis, Sistem ekonomi saat ini dengan adanya kesepakatan lintas negara baik dalam kawasan regional maupun multilateral yang mengandung liberalisasi ekonomi mengubah sistem hukum ekonomi yang berlandaskan Pasal 33 UUD 1945, menjadi sistem hukum yang berlandaskan liberalisme dan kapitalisme yang bertentangan dengan Pasal 33 UUD 1945. Pengembangan perekonomian Indonesia berdasarkan Pasal 33 UUD 1945

24 Sumantoro, Op.Cit, hlm.34. 
merupakan amanat dari Proklamasi yang bertujuan untuk kemakmuran rakyat. Liberalisasi ekonomi Indonesia pada akhirnya setahap demi setahap terintegrasi dalam sistem perekonomian pasar global berdasarkan kapitalisme. ${ }^{25}$.

Konsidi sejalan dengan pendapat Ahmad Muliadi seperti dikutip Asep Bambang Hermaanto ${ }^{26}$, bahwa swastanisasi atau privatisasi telah banyak terjadi pada kekayaan negara dengan cara menjual kepada investor luar. Hal ini menyebabkan investor asing berperang penting pada perekonomian negara dengan mengusai kekayaan alam yang penting yang seharusnya untuk kemakmuran masyarakat pada umumnya. Padahal selayaknya negara lah yang seharusnya menguasai dan mengendalikan kekayaaan lama tersebut. Hal ini berakibat penjabaran Pasal 33 UUD 1945 menjadi tidak jelas sebab peran negara dalam perekonomian tidak sepenuhnya berdaulat.

Penulis setuju dengan Asep Bambang Hermanto ${ }^{27}$ yang berkesimpulan bahwa politik hukum dari unsur pembuat peraturan perundang-undangan tidakselaras dengansitemekonomi Indonesiayangseharusnyamelaksanakan demokrasi ekonomi yang bercirikan ekonomi dan kekeluargaan dan mengembangkan koperasi di Indonesia.

Menyongsong satu abad kemerdekaan Indonesia pada tahun 2045, sebaiknya bangsa Indonesia kembali kepada UUD 1945, agar kita mempunyai kembali GBHN (Garis-Garis Besar Haluan Negara ) yang ditetapkan MPR yang merupakan represetasi seluruh masyarakat Indonesia.Tetapkan dalam GBHN tersebut visi dan misi Rakyat Indonesia 25 tahun ke depan yang bersendikan kemandirian dalam bidang ekonomi, tidak tergantung kepada asing untuk membangun Indonesia. Jadikanlah negara dan masyarakat ini menjadi negara dan masyarakat produktif seperti negara Cina yang mampu mengekspor berbagai macam barang ke penjuru dunia, termasuk negara kita. Hindari berlebihan menjadi negara dan masyarakat konsumtif apalagi berujung pada terkurasnya devisa negara kita.

Pemerintah memelopori dan mendukung untuk tumbuhnya industriindustri yang memproduksi barang sebagai substitusi impor dalam rangka menghemat devisa dan memperluas kesempatan kerja. Bantulah industri-

25 Revrisond Baswir, "Bahaya Liberalisasi Keuangan Bagi Negara-Negara Sedang Berkembang”, Makalah untuk Seminar Bulanan Pusat Studi Ekonomi Kerakyatan-UGM, dengan tema "Bahaya Liberalisasi Keuangan: Oleh-oleh dari Swiss, Leichenstein, dan Norwegia", tanggal 23 Juni 2006.

26 Asep Bambang Hermanto," Politik Hukum Dalam Demokrasi Ekonomi Indonesia” SELISIK-Volume 4, Nomor 7, Desember 2018,,hlm.9

27 Ibid. 
industri tersebut misalnya dalam keringan pajak atau diberi kemudahan perizinan.

Optimalkan tanah-tanah kosong yang masih tersebar luas di seluruh Indonesia untuk berswasebada kebutuhan yang sangat dibutuhkan masyarakat. Jangan sampai kebutuhan tersebut menjadi obyek barang impor. Galakan penelitian-penelitian untuk menghasilkan bibit unggul dan mampu berdaya tahan terhadap serangan hama.Turunkan harga pupuk supaya terjangkau petani untuk menghasilkan produk pertanian yang sangat banyak dan berkualitas.

\section{F. Kesimpulan}

Sistem ekonomi yang dianut oleh suatu negara di dunia terkait dengan idealogi yang dianut oleh suatu negara. Ideologi liberalisme melahirkan sistem ekonomi kapitalis, sebaliknya ideologi komunis melahirkan sistem ekonomi sosialis. Sistem ekonomi campuran merupakan sistem ekonomi yang berada di antara sistem ekonomi kapitalis dan sistem ekonomi sosialis. Sistem ekonomi Indonesia berdasarkan Pasal 33 UUD 45 bukan merupakan sitem ekonomi kapitalis dan bukan pula sistem ekonomi sosialis, namun arah kebijakan hukum ekonomi dalam pengembangan perekonomian Indonesia tidak mencerminkan Pasal 33 UUD 1945. Hukum ekonomi Indonesia bandulnya bergerak ke sistem ekonomi kapitalistik. Padahal seharusnya merupakan manifestasi dari sistem ekonomi campuran yang bersumber pada Pasal 33 UUD 45. Oleh karena rumusan hukum ekonomi bersumber Pasal 33 UUD 1945 dapat dimanifestasikan apabila terdapat GBHN yang memuat visi dan misi ekonomi untuk pembangunan ekonomi jangka pendek, jangka menengah dan jangka panjang yang berlaku untuk semua pemerintah yang berkuasa.

\section{Daftar Pustaka}

Adi Sulistyono, "Pembangunan Hukum Ekonomi Untuk Mendukung Pencapaian Visi Indonesia 2030" Pidato Pengukuhan Guru Besar Hukum Ekonomi Pada Fakultas Hukum UNS, Surakarta,17 Nopember 2007.

Asep Bambang Hermanto," Politik Hukum Dalam Demokrasi Ekonomi Indonesia" SELISIK- Volume 4, Nomor 7, Desember 2018.

Australian Government, Department of Foreign Affairs and Trade, "AsiaPacific Economic Cooperation (APEC)", tanpa tahun, <http://www. dfat.gov.au/apec/>, [2/05/2014]. 
Dumairy, Perekonomian Indonesia, Jakarta :Erlangga;1996.

Gopalan. Sasidaran and Ramkishen S. Pajan, "Financial Sector De-Regulation in Emerging Asia: Focus on Foreign Bank Entry", 13/1/10, < http://www. freewebs.com/rrajan1/bankentry.pdf >, [3/05/3015].

Joseph Nguyen," 5 Economic Effects Of Country Liberalization", <http:// www.investopedia.com/articles/economics/11/economic-benefitscountry-liberalization.asp?layout=orig. $>,[15 / 11 / 2015\}$.

Kamus Bahasa Indonesia online <http://kbbi.web.id/ideologi>. [22/10/2015].

Revrisond Baswir, "Bahaya Liberalisasi Keuangan Bagi Negara-Negara Sedang Berkembang", Makalah untuk Seminar Bulanan Pusat Studi Ekonomi Kerakyatan-UGM, dengan tema "Bahaya Liberalisasi Keuangan: Oleholeh dari Swiss, Leichenstein, dan Norwegia”, tanggal 23 Juni 2006.

Sumantoro, Hukum Ekonomi, Jakarta : UI-Press,2008.

The United Nation, "Economic liberalization and poverty reduction", <http:// www.un.org/esa/socdev/rwss/docs/2010/chapter6.>,[12/11/2015].

Wikipedia, the free encyclopedia, "Economic liberalization", <https:// en.wikipedia.org/wiki/Economic_liberalization>, [02/09/2015].

WTO, "Trade and Investment " <http://www.wto.org/english/tratop_e/ invest_e/invest_e.htm>, [2/10/2013].

Zulkarnain Sitompul, "World Trade Organization, International Monetary Fund Dan Perubahan Sistem Perbankan", Pro Justitia, Tahun XVI Nomor 4 Oktober 1998.

Undang-Undang Dasar 1945 